\title{
A checklist of metazoan parasites from albacore Thunnus alalunga (Bonaterre, 1788)
}

\begin{abstract}
A checklist of the metazoan parasites of host fish Albacore (Thunnus alalunga) was compiled from parasitological records published between 1940 and 2010. The checklist is arranged alphabetically, providing valid names and authorities of the parasite species, its capture sites, author(s) and date of published records. A total of 14 valid species are listed from T. alalunga. Parasite species where host data are missing or where the parasite was found not associated with a T. alalunga not are included.
\end{abstract}

Keywords: checklist, albacore, fish parasites, digenea, crustacea, monogenea
Mini Review

Volume 7 Issue I - 2018

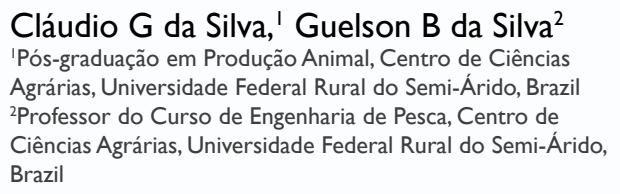

Correspondence: Cláudio G da Silva, Laboratório de Sanidade Aquática, Centro de Ciências Agrárias, Universidade Federal Rural do Semi-Árido, Rio Grande do Norte, Brazil, Email giovanio-sı@hotmail.com

Received: February 09, 2018 | Published: February 22, 2018

\section{Introduction}

The dispersion pattern of the parasites has been considered of great importance to the population dynamics of the parasite-host relationship, ${ }^{1,2}$ and the parasitic abundance dependent processes influence on survival and fertility of hosts. ${ }^{3}$ Generally, the damage caused to the host by parasitic diseases is related to the species of parasite, its form of feeding, organ or tissue of the affected host, intensity of the parasitism and to the general state of the host.,5 Parasitic infestations may delay the growth and weight gain of host fish when they affect food intake. ${ }^{6,7}$

The parasites are very useful for investigating the biology, ecology, migration and population structure bodies marine, ${ }^{8}$ and are also successfully used to clarify the various taxonomic relationships among its hosts. ${ }^{910}$ Various studies have been conducted over the years to determine the diversity and relative effect of parasitism in the world. ${ }^{11}$

Digeneans have a ventral or postero-ventral sucker, sometimes absent and the adults are primarily parasites of the gut, but they also occur free or incapsulated in the tissues of the vertebrates. ${ }^{12,13}$ Monogeneans are a group of largely ectoparasitic members of the phylum Platyhelminthes. These worms are considered to be among the most host-specific parasites in fish, commonly found on fins, body skin, gills, gill chambers, buccal cavity, cornea and nostrils of their host. ${ }^{14}$ The parasites Crustaceans are the most diverse and ubiquitous subphylum of arthropods in the seas. Most of the crustacean parasites are ectoparasites of a wide range of marine invertebrate and vertebrate organisms. ${ }^{15}$

The Albacore Thunnus alalunga (Teleostei: Scombridae) is a migratory cosmopolitan tuna distributed throughout tropical and temperate areas of all oceans, being one top level predator, and its diet varies according to size and availability of prey and the populations of this fish from different oceans are managed as separate stocks, based on the available evidence of geographical separation, and distinct spawning areas and seasons. ${ }^{16}$ In the world, there is no checklist of parasites that infest the host fish $T$. alalunga, which can generate deficiencies for the understanding of new studies.

This study is a start in correcting this deficiency by giving an updated checklist of the Metazoan parasites that infest the host fish Thunnus alalunga, using current and can be a useful tool for studying the parasite distribution as well as the general parasite diversity in $T$. alalunga, and it may also be an important tool for planning research activities in marine fish parasitology.

\section{Methods}

To compile the list parasites of Albacore Thunnus alalunga in the world, the records were obtained by searching the Scopus, Springer, SciELO, Web of Science, Elsevier, in the mechanism of search of Google Scholar and the Portal of Periodicals CAPES/MEC. To compile the data of the parasitic fauna of Albacore (T. alalunga) data were compiled from the following studies: Guiart \& Mele et al. ${ }^{16-19}$

\section{Checklist}

This metazoan parasite checklist includes only Digenea, Crustacea and Monogenea. This checklist was compiled from records published between 1940 and 2010, covering a total of 4 papers. The papers analysed by us recorded 14 valid species parasitizing $T$. alalunga. Reports of one parasite that had not been identified to the species level were included in this checklist. Parasite species where host data are missing or where the parasite was found not associated with a T. alalunga not are included. The results are presented as a list of parasite species in T. alalunga (Table 1). The specific distribution of species in the host fish is also recorded.

Studies of parasitic occurrences in Thunnus alalunga in the parasite groups Monogenea, Digenea and Crustacea were found between 1940 and 2010, of which there was a higher parasite occurrence in the Mediterranean Sea with 9 species identified, followed by Northeastern 
Atlantic Ocean with 7 species, Northwest Atlantic Ocean, Eastern Central Atlantic Ocean and Southwestern Atlantic Ocean with 1 species each (Figure 1).

It is noticed the importance of literature review works, since it facilitates the work of future researchers, when there is a checklist of a certain species. During the research, it is understood that there are few researches in the branch of parasitology there are few reports of parasite works of fish of the species T. alalunga, even with this species inhabiting the oceans.

Table I Checklist of the metazoan parasites of Albacore Thunnus alalunga (Parasite-Host list)

\begin{tabular}{|c|c|c|}
\hline Parasite species & Location & Author and record \\
\hline \multicolumn{3}{|l|}{ Monogenea } \\
\hline Capsala paucispinosa & Mediterranean Sea & Mele et al. ${ }^{16}$ \\
\hline Capsala thynni & Northeastern Atlantic Ocean & Dollfus ${ }^{18}$ \\
\hline \multicolumn{3}{|l|}{ Digenea } \\
\hline Didymocystis lanceolata & Northeastern Atlantic Ocean & Guiart $^{17}$ \\
\hline Didymocystis macrorchis & Northeastern Atlantic Ocean & Guiart $^{17}$ \\
\hline Didymocystis reniformis & Northeastern Atlantic Ocean & Guiart $^{17}$ \\
\hline Didymosulcus aahi & Mediterranean Sea & Mele et al. ${ }^{16}$ \\
\hline Didymosulcus dimidiatus & Mediterranean Sea & Mele et al. ${ }^{16}$ \\
\hline Didymozoon longicolle & Mediterranean Sea & Mele et al. ${ }^{16}$ \\
\hline Didymozoon pretiosus & Mediterranean Sea & Mele et al. ${ }^{16}$ \\
\hline Nematobothrium latum & $\begin{array}{l}\text { Mediterranean Sea } \\
\text { Northeastern Atlantic Ocean }\end{array}$ & $\begin{array}{l}\text { Mele et al. }{ }^{16} \\
\text { Guiart }^{17}\end{array}$ \\
\hline Wedlia bipartita & $\begin{array}{l}\text { Mediterranean Sea } \\
\text { Northeastern Atlantic Ocean }\end{array}$ & $\begin{array}{l}\text { Mele et al. }{ }^{16} \\
\text { Guiart }{ }^{17}\end{array}$ \\
\hline \multicolumn{3}{|l|}{ Crustacea } \\
\hline Euryphorus brachypterus & $\begin{array}{l}\text { Northeastern Atlantic Ocean } \\
\text { Northwest Atlantic Ocean } \\
\text { Eastern Central Atlantic Ocean } \\
\text { Southwestern Atlantic Ocean }\end{array}$ & $\begin{array}{l}\text { Dollfus }{ }^{18} \\
\text { Cressey and Cressey }^{19} \\
\text { Cressey and Cressey }{ }^{19} \\
\text { Cressey and Cressey }{ }^{19}\end{array}$ \\
\hline Pseudocycnus appendiculatus & Mediterranean Sea & Mele et al. ${ }^{16}$ \\
\hline Rocinela sp. & Mediterranean Sea & Mele et al. ${ }^{16}$ \\
\hline
\end{tabular}

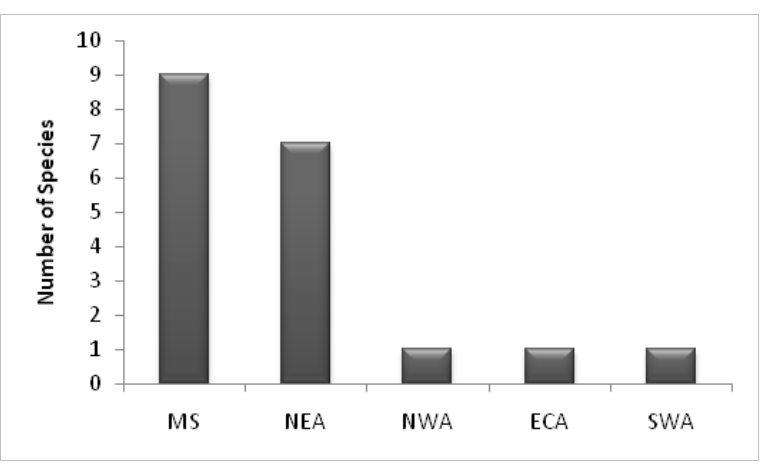

Figure I Distribution of parasitic species of Albacore (T. alalunga) in the oceans.

Abbreviations: MS, mediterranean sea; NEA, Northeastern Atlantic Ocean; NWA, Northwest Atlantic Ocean; ECA, Eastern Central Atlantic Ocean; SWA, Southwestern Atlantic Ocean.

\section{Acknowledgments}

None.

\section{Conflict of Interest}

The authors declare no conflict of interests.

\section{References}

1. Carvalho AR, Martins RT, Bellei PM, et al. Aspectos ecológicos da helmintofauna de Hopliasmalabaricus (Bloch, 1794)(Characiformes, Erythrinidae) da Represa Dr. João Penido (Juiz de Fora-MG, Brasil). Revista Brasileira de Zoociências. 2017;18:1.

2. Penczykowski RM, Laine AL, Koskella B. Understanding the ecology and evolution of host-parasite interactions across scales. Evolutionary Applications. 2016;9(1):37-52.

3. Visser MD, Schnitzer SA, Muller-Landau HC, et al. Tree species vary widely in their tolerance for liana infestation: A case study of differential host response to generalist parasites. $J$ Ecol. 2017;106:781-784. 
4. Choi YJ, Aliota MT, Mayhew GF, et al. Dual RNA-seq of parasite and host reveals gene expression dynamics during filarial worm-mosquito interactions. PLoS neglected tropical diseases. 2014;8(5):e2905.

5. Rynkiewicz EC, Pedersen AB, Fenton A. An ecosystem approach to understanding and managing within-host parasite community dynamics. Trends in Parasitology. 2015;31(5):212-221.

6. Barber I, Hoare D, Krause J. Effects of parasites on fish behaviour: a review and evolutionary perspective. Reviews in Fish Biology and Fisheries. 2000;10(2):131-165.

7. Bellay S, Ueda BH, Takemoto RM, et al. Fauna parasitária de Geophagus brasiliensis (Perciformes: Cichlidae) em reservatórios do estado do Paraná, Brasil. Revista Brasileira de Biociências. 2012;10(1):4-78.

8. MacKenzie K, Abaunza P. Parasites as biological tags. In: Cadrin, Kerr SX, Mariani S, editors. Stock identification methods. San Diego: Academic Press; 2014:185-203.

9. Whiteman NK, Parker PG. Using parasites to infer host population history: a new rationale for parasite conservation. Animal Conservation. 2005;8(2):175-181

10. Mele S, Saber S, Gómez-Vives MJ, et al. Metazoan parasites in the head region of the bullet tuna Auxis rochei (Osteichthyes: Scombridae) from the western Mediterranean Sea. Journal of Helminthology. 2014;89(6):734-739.

11. Appeltans W, Ahyong ST, Anderson G, et al. (2012) The magnitude of global marine species diversity. Curr Biol. 2012;22(23):2189-2202.
12. Cribb TH. Digenea (endoparasitic flukes). In: Rohde K, editor. Marine parasitology. Wallingford: CABI Publishing; 2005. p. 76-86.

13. Bray RA, Gibson DI, Jones A. Keys to the Trematoda. CAB International and Natural History Museum, Wallingford; 2008. p. 1-848.

14. Costa EF, Chellappa S. First record of Amphipolycotyle chloroscombrus Hargis, 1957 (Monogenea, Polyopisthocotylea, Gastrocotylidae) in the South Atlantic Ocean. Brazilian Journal of Oceanography. 2016;64(1):101-104.

15. Rohde K. Marine parasitology. Wallingford: CABI Publishing; 2005. pp. $1-590$.

16. Mele S, Merella P, Macias D, et al. Metazoan gill parasites of wild albacore Thunnusalalunga (Bonaterre, 1788) from the Balearic Sea (western Mediterranean) and their use as biological tags. Fisheries Research. 2010;102(3):305-310.

17. Guiart J. Trématodes parasites provenait des campagnes scientifiques du Prince Albert 1 de Monaco (1886-1912). Résultats des Campagnes Scientifiques de Prince Albert. 1940;100:1-75.

18. Dollfus RP. Parasites du Germoalalunga (Gmelin 1788). ICES J Mar Sci.1952;18(1):42-44.

19. Cressey R, Cressey HB. Parasitic copepods of mackerel and tuna-like fishes (Scombridae) of the world. Smithson. Contrib Zool. 1980;311:1186. 